\title{
THE POLICE POWER AND ECONOMIC RECONSTRUCTION
}

\author{
Ray A. Brown and Howard I. Hall*
}

I

N

EARLY thirty years ago Professor Ernst Freund published his well-known work, "The Police Power." Like all of Professor Freund's writings, it was closely analytical, exhaustive, and scholarly. Examining the concept of the police power, he defined it as "the power of promoting the public welfare by restraining and regulating the use of liberty and property." The noted author's discussion of the police power was necessarily bifurcate. There was the problem on the one hand of the objectives Jegally to be comprehended under the broad general purpose of promoting the public welfare, and on the other, of the private interests restricted or abolished in the attainment of the broader social end. To the first part of the problem Professor Freund devoted over one-half his work. Police power objectives were placed in two general categories, first, the protection of so-called "primary social interests," the safety, order, and morality of the community; and second, the advancement of economic interests, that is, the control by the state of those processes by which the material goods of the world are acquired, possessed, and distributed. Concerning the use of the police power for these two general objectives, Professor Freund said, "That the organized community should afford its members protection against physical danger and moral scandal is generally admitted, and only the question to what extent this protection should go, is controverted. It is otherwise as to economic interests. Wealth is almost as essential to our civilization as safety, order, and morals; but while these can be secured to a substantial degree by restraint, the acquisition of wealth is based on active efforts; and while systematic restraint proceeds naturally from our government, active effort must be chiefly individual. Our economic system is essentially individualistic, and, more than that is based upon peaceful struggle and conflict. An absolute governmental control over economic interests, similar to that over the interests of order, peace, and security would be possible only if with regard

* Professors of Law, University of Wisconsin Law School.

× Ernst Freund, The Police Power, Public Policy and Constitutional Rights (IgO4).

2 Freund, op. cit., sutpra, note $\mathrm{r}$, iii. 
to the former as well as with regard to the latter, equality were a desirable or practicable end, i.e., if the state were socialistic." 3

Professor Freund's "Police Power" preceded the great development of that subject by the United States Supreme Court. Such leading and significant cases as Lochner v. New York, ${ }^{4}$ Jacobson v. Massachusetts, ${ }^{5}$ Adair v. United States, ${ }^{6}$ Muller v. Oregon ${ }^{7}$ and Noble State Bank v. Haskell, ${ }^{8}$ were all decided after the appearance of the "Police Power" in Igo4. Professor Freund's analysis had in it, however, a very considerable amount of prophetic vision. Where legislation has been directed towards the advancement of public health, safety, or morals, the Supreme Court has quite consistently sustained it.9 Its refusal to sanction certain laws because of a belief that either the claimed danger to the public interest did not exist, ${ }^{10}$ or that the burden placed upon the restricted private right was too great to justify a supposed public advantage, ${ }^{\mathrm{xx}}$ cannot be taken as showing disbelief in the propriety of the statute's purpose in and of itself. Even economic interests have been secured in a large number of instances, carefully catalogued by Professor Freund..$^{12}$ The police power, as well as the ordinary civil and criminal laws, protect against fraud. ${ }^{{ }^{3}}$ Gambling and stock market speculation to the frequent ruin of those indulging have been validly prohibited, perhaps because of an element of the immoral. ${ }^{{ }^{4}}$ Usury and bankruptcy laws preserve for the debtor a minimum of economic existence. ${ }^{15}$ The odiousness of monopolies and combinations in restraint of trade raising prices to artificial levels has been generally admitted, ${ }^{16}$ and the power of the state to regulate charges of businesses affected with a

3 Freund, op. cil., supra, note $\mathrm{r}, 8$.

4 I 98 U.S. 45,25 Sup. Ct 539, 49 L.Ed. 937 (I905).

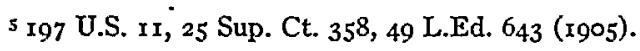

0208 U.S. I6r, 28 Sup. Ct. 277,52 L.Ed. 436 (rgo8).

7208 U.S. 412, 28 Sup. Ct. 324, $5^{2}$ L.Ed. $55^{1}$ (1908).

${ }_{219}$ U.S. 104, 31 Sup. Ct. 186, 55 L.Ed. 112 (I9II).

9 Brown, Police Power, Legislation for Health and Personal Safety, 42 Harv. L. Rev. 866 (I929).

so Weaver v. Palmer Brothers Co., 270 U.S. 402, 46 Sup. Ct. 320, 70 L.Ed. 654 (I926).

II Pennsylvania Coal Co. v. Mahon, 260 U.S. 393, 43 Sup. Ct., I58, 67 L.Ed. 322 (I922).

12 Freund, op. cit., supra, note $\mathrm{r}, 260-294$.

${ }^{23}$ Hall v. Geiger-Jones Co., 242 U.S. 539, 37 Sup. Ct. 217, 6r L.Ed. 480 (I9r7).

I4 Otis v. Parker, I 87 U.S. 606, 23 Sup. Ct. I68, 47 L.Ed. 323 (1903). Professor Freund classified such legislation as tending to promote public morals, pp. 172-19I.

15 Freund, op. cit., supra, note 1, 288-293.

${ }^{16}$ See Sherman Anti-Trust Act and the Clayton Act, $x_{5}$ U.S.C. $\$ 1-27$. 
public interest, declared in the early case of Munn v. Mllinois ${ }^{17}$ has been recognized. In the above classes of cases no serious charge can be made that the court has substantially interfered with legislative prerogatives. In a number of cases, indeed, it has found a permissible objective in the legislation at hand, where it seems likely that the true purpose was of a much more questionable character..$^{18}$

In spite of this liberal interpretation of the police power in the fields above indicated, it is apparent that the welfare of the public has by no means as yet been achieved. Even as to the pre-depression era high official authority ${ }^{19}$ was compelled to speak guardedly. The enumeration of the ills of specific industries, and of the agricultural classes ${ }^{20}$ need not be repeated here. Although the condition of labor was reported generally satisfactory as compared to the pre-war period, nevertheless there was "a large and persistent volume of unemployment even in the very active years. ${ }^{21}$ There was, moreover, a feeling in many circles that the prosperity of the post-war decade was very unevenly distributed. Two hundred large corporations controlled over one-third of the nation's business wealth. ${ }^{22}$ In 1929, five hundred four individuals had average annual incomes of over two million three hundred and fifty thousand dollars each. The aggregate income of these five hundred odd individuals was approximately as great as the value of all the wheat and cotton grown in the country in a year by over two and one-third million farmers. ${ }^{23}$ Of all persons gainfully employed, over ninety-four percent received less than three thousand dollars per annum ${ }^{24}$ while at the bottom of the scale, near the starvation level, even in times of plenty, were millions of unskilled Jaborers, concerning whom the Secretary of Labor in President Hoover's Cab-

${ }^{17} 94$ U.S. II3, 24 L.Ed. 77 (1877). See Robinson, The Public Utility Concept in American Law, 4I Harv. L. Rev. 277 (rg28).

${ }^{18}$ See Rast v. Van Deman \& Lewis Co., 240 U.S. 342, 36 Sup. Ct. 370, 60 L.Ed. 79 (1916); Hebe Co. v. Shaw, 248 U.S. 297, 39 Sup. Ct. I25, 63 L.Ed. 255 (x9r9).

19 Report of Committee on Recent Economic Changes, President's Conference on Unemployment (rg29).

${ }^{20}$ Ibid., x; Ibid., Special report on agriculture, Edwin G. Nourse, 547.

${ }^{2 x}$ Ibid., Special report on condition of labor, Leo Wolman, 492.

22 Gardiner Means, The Growth in the Relative Importance of the Large Corporation in American Economic Life, 2r Amer. Econ. Rev. Io-37 (I93I). See Berle \& Means, The Modern Corporation and Private Property (r932).

${ }^{23}$ The figures are taken from note 55 in the dissent of Mr. Justice Brandeis in Louis K. Liggett Co. v. Lee, 288 U.S. 517, 53 Sup. Ct. 48r, 77 L.Ed. 553 (1933). Mr. Justice Brandeis' dissent is heavily annotated with references to material bearing on the growth of the great American corporations.

${ }^{24}$ Nystrom, Economic Principles of Consumption (r929), r80 et seq. 
inet said, "If we think of those in all our industries who may lack mechanical skill but who nevertheless shoulder the heavy weights and do the roughest work, we find a great part of American industry shot through with these unfortunates. It is not an exaggeration to say that we have some millions of these hard-worked but underpaid Americans. Taken together with their families and their dependents, I would venture to say that we have among us from ten to fifteen millions of people who do not share as they should in the prosperity enjoyed by the rest of us. Morally, economically, and on the grounds of simple humanity, this inequality should not be allowed to exist in this richest nation in history." ${ }^{25}$

To this pre-existing dissatisfaction, the market crash of 1929 and the ensuing years of depression have added fuel to the flames of discontent. Statistics of unemployment, farm foreclosures, bank failures, and families on public charity were not required to convince most people that our economic society was badly out of joint, and there arose a strident cry that something be done about it. President Franklin D. Roosevelt in his recent book, "Looking Forward," published just before he assumed the presidency, said, "We have not been brought to our present state by any natural calamity, by drouth, or floods, or earthquakes, or by the destruction of our productive machinery or man power. We have a superabundance of raw materials, of equipment for manufacturing these materials into the goods which we need, and transportation and commercial facilities for making them available to all who need them. A great portion of our machinery stands idle, while millions of able-bodied and intelligent men and women in dire need are clamoring for the opportunity to work. Our power to operate the economic machine we have created is challenged." ${ }_{26}$ There were those who were convinced that the assumed individualistic basis for our economic life would have to be abandoned. In the words of one writer, "The battle for an individualistic laissez-faire economy is definitely lost. . . . We shall do well to avert our eyes from the pretense that we can achieve a fundamentally individualistic society..... Why not frankly acknowledge that sensible management for collective purposes is the necessary control, and see what we can do to achieve it?"'27 Others, without such frank abnegation of individualistic economics, also proposed governmental controls over the economic system that a decade

${ }^{25}$ Address of James J. Davis, June 22, I927, quoted in Nystrom, op. cit., supra, note 24, I83.

${ }^{26}$ Franklin D. Roosevelt, Looking Forward (1933), 45.

${ }_{77}$ George Soule, A Planned Society (1932), 172. See also Tugwell, An Industrialized Society (1933), 33. "The appeal to laissez faire in industry, for instance, has come to be a mere partisan request for leave to engage in a street brawl which interferes with the legitimate pursuits of everyone else. It becomes more and more clear that these freedoms have to be restricted." 
ago would have been considered radical. Back in I929, Wesley C. Mitchell reporting for the Committee on Recent Economic Changes of President Hoover's Conference on Unemployment, said, "If we are to maintain business prosperity we must continue to earn it month after month and year after year by intelligent effort. The incomes disbursed to consumers and to wage earners in particular must be increased on a scale sufficient to pay for the swelling volume of consumer's goods sent to market. The credit structure must be kept in dual adjustment to the earnings of business enterprise. . . . Commodity stocks must be held in line with current sales. Overcommitments of all sorts must be avoided." ${ }^{28}$ The same ideas were echoed later by the president elect, "I believe that we are at the threshold of a fundamental change in our economic thought. I believe that in the future we are going to think less about the producer and more about the consumer. Do what we may to inject health into our ailing economic order, we cannot make it endurè for long unless we can bring about a wiser, more equitable distribution of the national income. It is well within the inventive capacity of men, who have built up this great social and economic machine capable of satisfying the wants of all, to insure that all who are willing and able to work receive from it at least the necessities of life. In such a system, the reward for a day's work will have to be greater, on the average, than it has been, and the reward to capital, especially capital which is speculative, will have to be less." ${ }^{29}$

\section{II}

In answer to the popular demand for action to relieve the economic distress, and in concrete realization of the philsosophy that subordinates private rights of property and contract to social needs, legislative bodies the country over have considered and enacted many laws. Based on the premise that there is a gross inequality in bargaining power between the employer and the employee, and that the labor union must be preserved and encouraged as a necessary instrument for advancing the workers' interests, eight states have passed statutes declaring void agreements, exacted from the employee as a condition of his employment, not to join a labor union. ${ }^{30}$ For the purpose of providing a modicum of income to workers deprived of their jobs by industrial causes beyond their own control, and

${ }^{28}$ Report of Committee on Recent Economic Changes, supra, note I9, 909.

${ }^{29}$ Roosevelt, op. cit., supra, note 26,49 . See also President Roosevelt's campaign speech at San Francisco, N.Y. Times, Sept. 24, I932.

${ }^{30}$ Arizona, Colorado, New Jersey, Ohio, Oregon, Pennsylvania, Utah and Wisconsin. See 21 Am. Lab. Leg. Rev. 295 (1931); 22 Am. Lab. Leg. Rev. I68-I72 (r932); 40 American Federationist 632-635 (I933). See also, Witte, "Yellow Dog" Contracts, 6 Wis. L. Rev. 21 (1930). 
as an incentive to employers to stabilize employment throughout the calendar year, laws have been enacted requiring employers to maintain for their employees unemployment insurance or reserve funds. ${ }^{3 x}$ Thus unemployment is added to industrial accident and disease as a risk of industry to be borne at least in part by the employer and ultimately by the consuming public..$^{32}$ Farmers' strikes and the spectacle of roads picketed to prevent the carriage of milk to market have produced acts in at least four states to fix the price of milk in the interests of an admittedly under-compensated agricultural producer. ${ }^{33}$ In spite of the decision of Adkins v. Children's Hospital, ${ }^{34}$ this year five states enacted legislation attempting to guarantee to women and minors a minimum wage to be determined by a state commission; ${ }^{35}$ and nine other states already possess such Jegisla-

${ }^{31}{ }_{23}$ Am. Lab. Leg. Rev. 9 and 73 (1933). The Democratic party and President Roosevelt have both publicly declared in favor of unemployment insurance. Roosevelt, op. cit., supra, note 26 , II6.

${ }^{32}$ Wisconsin Laws, Special Session, r93 $x-\mathrm{r} 93^{2}$, Chap. 20, Amended, Laws of 1933 , Chaps. I 86 and 383 . See Brandeis and Raushenbush, Wisconsin's Unemployment Reserves and Compensation Act, 7 Wis. L. Rev. I36 (r932); Lambert, Compulsory Unemployment Insurance and Due Process of Law, 7 Wis. L. Rev. $4_{4} 6$ (1932); Jacobson, The Wisconsin Unemployment Compensation Act, 32 Col. L. Rev. 409 (1932); Commons, The Groves Unemployment Reserves Law, 22 Am. Lab. Leg. Rev. 8 (r932); Raushenbush, Wisconsin's Unemployment Compensation Act, $22 \mathrm{Am}$. Lab. Leg. Rev. Ir (1932); Goodrich, Unemployment Reserves by Law; 22 Am. Lab. Leg. Rev. 33 (r932). This proposed legislation falls into two types: first, that based upon an insurance idea, sometimes called the Ohio plan; and second, the reserve plan. For a critical discussion of the two types of plans, see article by Karl T. Compton in $23 \mathrm{Am}$. Lab. Leg. Rev. 96 (1933). Mr. Compton points out that under the insurance plan the funds are pooled by the state. He feels that this would work in normal times, but would break down in times of serious depression. Under the reserve plan each employer's contribution would be credited to him, and his contribution cease when a certain amount per employee would be reached, thus tending to make the employer stabilize employment. Mr. Compton cites figures to show that in Massachusetts the average cost would have been four-tenths of one cent per sales dollar, and that had the plan been in effect prior to the present depression the reserve funds would have reached $\$ 70, \infty \infty, \infty \infty)$.

${ }_{33}$ N.Y. Laws of $x 933$, Chap. I58; N.J. Laws of 1933 , Chap. I69; Wis. Laws 1933 , Chap. 64; Ohio, 1933, H.B. No. 67I (session laws not available); also Manitoba, I933 (session laws not available). These bills have been made available through the courtesy of the Wisconsin Legislative Reference Library, State Capitol, Madison, Wisconsin. The New York act became law April ro, 1933. Section 300 provides, "This article is enacted in the exercise of the police power of the state, and its purposes generally are to protect the public health and public welfare." Other section headings are: 302-Milk Control Board; 308-Licenses to Milk Dealers; 312Order Fixing Price of Milk; 314-Interstate and Federal Compacts; 319-Duration of Board (termination March 3x, 1934). The rules and orders issued, and forms prescribed, by the boards in New York and New Jersey are now available in mimeographed and printed form.

${ }^{34}$ 26I U.S. 525, 43 Sup. Ct. 394, 67 L.Ed. 785 (r923).

35 Tllinois, New Hampshire, New Jersey, New York, and Utah. The Illinois act is Senate Bill No. 730 (session laws not available); for text of latter four acts see Monthly Labor Review, issue of June 1933 . 
tion. ${ }^{36}$ The preamble to the Illinois act, repudiating former individualistic notions and clearly expressing the social philosophy on which it is based, declares, "Many women and minors employed for gain in the state of Mllinois are not as a class equally equipped for bargaining with their employers in regard to a minimum fair wage and standards, and 'freedom of contract' as applied to their relations with their employes is in many cases illusory." The other statutes contain similar provisions. Lastly come the proposals to control through the power of the government the supply of goods and productive machinery to the end that capital be not wasted in unwise ventures; the labor market be not disturbed; and eras of alternating hilarious prosperity and melancholic depression be banished. ${ }^{37}$

The "National Industrial Recovery Act," of June r6, I933, the "N.I.R.A.," ${ }^{8}$ in its possible effect on the country's economic, political and

${ }^{36}$ California, Colorado, Massachusetts, Minnesota, North Dakota, Oregon, South Dakota, Washington, and Wisconsin. A news item in the New York Times for March 23, I933 reported that Professor Felix Frankfurter had issued a warning that the New York legislature should not include men in the statute or it would be declared unconstitutional. The New York Act in the preamble states the factual background and declares an emergency. Section $55^{\circ}$ continues, "The evils of oppressive, unreasonable and unfair wages are such as to render imperative the exercise of the police power of the state for the protection of industry and of the men and women and minors employed therein, and of the public interest of the community at large in their health and well-being and in the prevention of the deterioration of the race."-Quoted from Senate Bill No. 1868, March 22, r933. The Calendar of Bills introduced into the New York Legislature for 1933 lists sixty labor bills. The American Federationist, June I933, 632636 , shows the progress of various labor bills in the state legislatures. A bill concerning hours of labor for women and minors was introduced in the Connecticut Legislature (Senate Bill No. 470). For legislation proposed and enacted concerning wages and hours of labor, see U.S. Dept. of Labor, Women's Bureau, News Letters vol. XIII, No. 6, June I, 1933. It is to be noted that the enactments do not attempt to fix a living wage. The recent minimum wage statutes contain penalties on employers, and a granting to employees of a right to recover the balance of minimum wages unpaid in a civil action against the employer. E.g., N.H. Act, sec. 23 ; N.J. Act, sec. I6; N.Y. Act, sec. 566; Utah Act, sec. I3.

${ }^{37}$ In the special session of the r93 $\mathrm{r}$ Wisconsin Legislature a measure known as Bill No. $3 \mathrm{~A}$ was introduced with the sanction of Governor LaFollette to foster economic planning. It did not, however, pass. See also, Roosevelt, op. cit., supra, note 26,47 et seq. "That, which seems most important to me in the long run is the problem of controlling by adequate planning the creation and the distribution of those products, which our vast economic machine is capable of yielding. I do not mean to curtail new enterprise. But think carefully of the vast sums of capital or credit which in the past decade have been devoted to unjust enterprises- to the development of unessentials and to the multiplication of many products far beyond the capacity of the nation to absorb. . . . . It is towards stability that we must move if we are to profit by our recent experience. . . . . Let us not confuse objectives with methods. . . . When the nation becomes substantially united in favor of planning the broad objectives of civilization, then true leadership must unite thought behind definite methods. The country needs and, unless I mistake its temper, demands bold, persistent experimentation. It is common sense to take a method and try it; if it fails, admit it frankly and try another. But above all try something. ...." See also Wesley C. Mitchell, supra, note 28 .

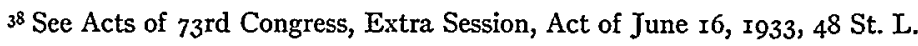


legal history overshadows all other current legislation, and perhaps all other legislation since the constitution was first promulgated. ${ }^{39}$ Although it presents compelling questions concerning the federal and executive power granted, we can only consider it here as an expression of the power of the government over individual economic interests. The preamble, after declaring a national emergency, clearly proclaims the determination of the government to take a direct part in controlling our economic system for the general good of all our people. . ... "It is hereby declared to be the policy of Congress . . . . to provide for the general welfare by promoting the organization of industry for the purpose of co-operative action among trade groups, to induce and maintain united action of labor and management under adequate governmental sanctions and supervision, to eliminate unfair competitive practices, to promote the fullest possible utilization of the present productive capacity of industries, to avoid undue restriction of production (except as may be temporarily required), to increase the consumption of industrial and agricultural products by increasing purchasing power, to reduce and relieve unemployment, to improve standards of labor, and otherwise to rehabilitate industry and to conserve natural resources." Section three of the act provides for the voluntary submission by trade or industrial groups of codes of fair competition. Such codes are, however, subject to presidential approval, and, "the President may as a condition of his approval ... impose such conditions ... . for the protection of consumers, competitors, employees, and others, and in furtherance of the public interest, and may provide such exceptions to and exemptions from the provisions of such code, as the President in his discretion deems necessary to effectuate the policy herein declared." Moreover, if any trade or industry fails to present a code capable of securing presidential approval, "the President after such public notice and hearing as he shall specify, may prescribe and approve a code of fair competition for such trade or industry." Again, if the President finds that any trade, industry, or subdivision thereof is engaging in activities contrary to the policy declared in the preamble, for the purpose of securing effective codes of fair competition he may require a license of those engaged in such trades and industries, and thereafter, if interstate or foreign commerce is thereby affected, it becomes a criminal offence to engage in such trade or industry without the presidential license..$^{40}$ Ap-

${ }^{39}$ See President Roosevelt's statement on signing the National Industrial Recovery Act, "History probably will record the National Industrial Recovery Act as the most important and far-reaching legislation ever enacted by the American Congress. It represents a supreme effort to stabilize for all time the many factors which make for the prosperity of the nation, and the preservation of American standards."

${ }^{40} S u p r a$, note $38, \$_{4}$. 
propriate penal sanctions are also provided for violations of the codes of fair competition.

Although up to the time of the present writing this far-reaching legislation has depended largely on voluntary action spurred on by exhortation, banners, and parades, nevertheless it is still a mailed fist concealed in a silken glove. The President has exercised his power of deleting from the voluntary codes provisions deemed inimical to the purposes of the statute, ${ }^{4 \mathrm{I}}$ and back of it all lies the yet unused sanctions of the licensing power and the criminal prosecution. While there is a tendency of the proponents of the law, in defending its provisions against the doubts of the timid, conservative, and legally minded, to aver that it is only a normal exercise of the traditional powers of government, yet these same defenders almost in the same breath recognize its truly revolutionary character..$^{42}$ As stated by a learned commentator, "The organization of industry which it will foster, and the sanctions it provides to effectuate its purposes, involve a distinct revision of the traditional legal view of free private enterprise and competition developed by the Supreme Court of the United States in interpreting the Constitution and the federal anti-trust laws." 43 The chief of the legal division of the National Recovery Administration in a radio address of July 3 Ist, wondered how many of "the fortunate people of this country understand that the long discussed revolution is actually under way in the United States. There is no need to prophesy. It is here. It is

${ }^{4 x}$ See order of the president of September 18 , I933, eliminating from the code submitted by the bituminous coal industry certain provisions attempting to construe section 7 (a) of the National Industrial Recovery Act relating to the right of collective bargaining on the part of employees.

42 Cf. Senator Robert F. Wagner before the Committee on Finance of the United States Senate in the hearings on the bill. "The bill marks a far-reaching departure from the philosophy that the government should remain a silent spectator while the people of the United States, without plan and without organization, vainly attempt to achieve their social and economic ideals. It recognizes that planlessness and disjunctive efforts lead to waste, destruction, exploitation and disaster and that purposive planning awaits the substitution of regulated planning in place of the unlimited and frequently pernicious competition which we have heretofore regarded as the sole guardian of the public welfare. This trend in thought and action is accompanied by a widening concept of business - that all business is affected with a public interest." Later in the same hearing, he said, "We are not seeking a change; we are seeking a rationalization of competition, instead of permitting the sweatshop, by exploitation of labor, to break us down by its competition. . . . We regulate the hours of labor within a state. We regulate all sorts of things and it has become necessary. The same argument was used when we tried to pass the workmen's compensation law within the states. Today that philosophy is accepted. . . . . The bill is drawn to expire at the end of two years. It is frankly an experiment. But it is an experiment worth making. . . . " Reported in Federal Trade Regulation Service, C. C. H. (7th ed. I933), I944 et seq.

${ }_{43} \mathrm{Kirsh}$, The National Industrial Recovery Act (I933), II-r2. 
in process. In this favored land of ours we are attempting, possibly, the greatest experiment in history." ${ }_{44}$

\section{III}

These laws, state and federal, present a radical advance in American economic, political, and legal theory. Sooner or later the highest courts of the states and of the nation must determine whether they are permissable under our constitutional government. Specifically the question will be, is the police power concept sufficient to over-ride the individual rights of property and contract hitherto protected by the due process of law clauses of the Fifth and Fourteenth Amendments. There have, indeed, been broad and liberal interpretations of the police power in the opinions of the United States Supreme Court. ${ }^{45}$ Nevertheless, when the question has been squarely presented and legislation has attempted to throw the weight of the state into certain types of bargains, in order to secure for the economically inferior party a fairer and more equal contract, the Supreme Court has almost invariably decided in favor of unrestrained bargaining power, and adopted, at times expressly, at times impliedly, an individualistic theory of the concepts of property and contract.

Because of the millions directly affected, state power has been most commonly exerted in favor of labor..$^{46}$ Where the purpose has been to protect health and bodily safety, or to prevent practices akin to fraud or oppression, the legislation has been sustained. Some of the earlier opinions indeed strongly intimated that the state might, simply because of the

4 See New York Times, August I, I933. Compare the above statement with that made in an address delivered in New York City, July 6 th. "There is no change of any provision of the Constitution attempted in this law. Therefore all the time-honored constitutional rights of the individual remain unmodified by this law. Second, there exists no constitutional right to do anything which is forbidden by this law. There is no constitutional right to compete unfairly; and there is no business competition which is more unfair or more harmful to all the people than the competition of low wages and long hours which the National Recovery Act seeks particularly to eliminate." This statement may be correct if we ignore the fact that the Supreme Court of the United States and not Mr. Richberg is the expositor of the Constitution. The authors of this article do not, of course, attempt to declare what may be the decision of the Court when this legislation is finally presented to it. The past opinions of the Court, however, seem to be clearly out of harmony with Mr. Richberg's declaration.

45 "It may be said in a general way that the police power extends to all the great public needs. . . . . It may be put forth in aid of what is sanctioned by usage, or held by the prevailing morality or strong and preponderant opinion to be greatly and immediately necessary to the public welfare." Holmes J. in Noble State Bank v. Haskell, 219 U.S. I04, III, 3 I Sup. Ct. I86, x88, 55 L.Ed. $x x_{2}$ (I9II). The police power "extends to so dealing with the conditions which exist in the State as to bring out of them the greatest welfare of its people." McKenna J. in Bacon v. Walker, 204 U.S. 3I I, 3I8, 27 Sup. Ct. 289, 29r (I907).

${ }_{46}^{6}$ See stopra, note 36 , for data concerning number of recent labor bills. 
economic inequality between employer and employee, exert its power in behalf of the weaker party. Thus in Holden v. Hardy, ${ }^{47}$ an hours of labor case, the court through Mr. Justice Brown said, "The proprietors of these establishments and their operatives do not stand upon an equality and .... their interests are to a certain extent conflicting. The former naturally desire to obtain as much labor as possible from their employees, while the latter are often induced by the fear of discharge to conform to regulations which their judgment fairly exercised would pronounce to be detrimental to their health or strength. In other words, the proprietors lay down the rules and the laborers are practically constrained to obey them." ${ }^{48}$ Again, in Knoxville Iron Co. v. Harbison, ${ }^{49}$ the court sustained a Tennessee statute requiring that all orders for merchandise given in payment of wages be redeemable at their face value in cash. The court quoted with approval the supreme court of the state: "The statute's tendency, though slight it may be, is to place the employer and employee upon equal ground in the matter of wages, and so far as calculated to accomplish that end, it deserves commendation." ${ }_{50}$ The current, however, soon turned in the other direction. Lochner v. 'New York ${ }^{5 x}$ can be disposed of, perhaps, on the ground that as a health measure it was not justified by the facts. Mr. Justice Peckham, who wrote the majority opinion, however, went further and read into "due process" a declaration in favor of the individualistic philosophy of Adam Smith, Ricardo and Herbert Spencer. "There is no reasonable ground for interfering with the liberty of person or the right of free contract, by determining the hours of labor in the occupation of a baker. There is no contention that bakers as a class are not equal in intelligence and capacity to men in other trades or manual occupations, or that they are not able to assert their rights and care for themselves without the protecting arm of the state interfering with their independence of judgment and of action. They are in no sense wards of the state. Viewed in the light of a purely labor law, with no reference whatever to the question of health, we think that a law like the one before us involves neither the safety, the morals, nor the welfare of the public, and that the interest of the public is not in the slightest degree affected by such an act." ${ }_{52}$

${ }^{*}{ }_{47}$ I69 U.S. 366, r8 Sup. Ct. 383,42 I.Ed. 780 (r898).

$4^{8}$ Ibid., 397 .

${ }_{49}$ I 83 U.S. I3, 22 Sup. Ct. I, 46 L.Ed. 55 (Igor).

${ }^{50}$ Ibid., 20.

${ }_{5 x}^{5}$ r98 U.S. 45, 25 Sup. Ct. 539, 49 L.Ed. 937 (I905).

52 Ibid., 57. Compare the well-known dissent of Holmes in this case at pages 75-76: "This case is decided upon an economic theory which a large part of the country does not entertain. If it were a question whether I agreed with that theory, I should desire to study it further and 
Both Adair v. United States ${ }^{53}$ and Coppage v. Kansas ${ }^{54}$ involved statutes making it a crime for the employer to interfere with the employee's right to join a labor union by discharge, threats of discharge, or by imposing restrictive agreements in the contract of employment. In the former case Mr. Justice Harlan found it unconstitutional for the state to restrict the right of either party to the relation to terminate it at will, declaring that, "in all such particulars the employer and employee have equality of right, and any legislation that disturbs that equality is an arbitrary interference with the liberty of contract, which no government can legally justify in a free land."'ss In the latter case Mr. Justice Pitney, speaking for the majority of the court, in answer to a suggestion that the statute was justified by the inequalities between employer and employee, said: "No doubt, wherever the right of private property exists, there must and will be inequalities of fortune; and thus it naturally happens that parties negotiating about a contract are not equally hampered by circumstances. This applies to all contracts, and not merely to that between employer and employee. . . . . And, since it is self evident that, unless all things are held in common, some persons must have more property than others, it is from the nature of things impossible to uphold freedom of contract and the right of private property without at the same time recognizing as legitimate those inequalities of fortune that are the necessary result of the exercise of those rights. But the Fourteenth Amendment, in declaring that a State shall not 'deprive any person of life, liberty or property without due process of law' gives to each of these an equal sanction; it recognizes 'liberty' and 'property' as co-existent human rights, and debars the States from an unwarranted interference with either. And since a State may not strike them down directly it is clear that it may not do so indirectly, as by de-

long before making up my mind. But I do not conceive that to be my duty, because I strongly believe that my agreement or disagreement has nothing to do with the right of a majority to embody their opinions in law. . . . The Fourteenth Amendment does not enact Mr. Herbert Spencer's Social Statics. . . . A constitution is not intended to embody a particular economic theory, whether of paternalism and the organic relation of the citizen to the State or of laissez faire. It is made for people of fundamentally differing views, and the accident of our finding certain opinions natural and familiar or novel and even shocking ought not to conclude our judgment upon the question whether statutes embodying them conflict with the Constitution of the United States." The precise effect of this case has been largely nullified by later decisions. See Muller v. Oregon, 208 U.S. 4I2, 28 Sup. Ct. 324, 52 L.Ed. 55I (I908); Bunting v. Oregon, 243 U.S. 426,37 Sup. Ct. 435 , 6I L.Ed. 830 (r9I7), and see dissents of Taft C.J. and Holmes J. in Adkins v. Children's Hospital, 26I U.S. 525, 43 Sup. Ct. 394, 67 L.Ed. 785 (I923).

53208 U.S. 16I, 28 Sup. Ct. 277, 52 L.Ed. 436 (I908).

54236 U.S. I, 35 Sup. Ct. 240,59 L.Ed. 44 I (I9I5).

s Supra, note $53, \mp 75$. 
claring in effect that the public good requires the removal of those inequalities that are but the normal and inevitable result of their exercise, and then invoke the police power in order to remove the inequalities, without other object in view." ${ }_{56}^{6}$

These are hard words to meet when it is proposed that in order to preserve our economic establishment, it is necessary to decrease the awards to capital and increase those of labor. Nearly a decade later came a more direct attempt to secure to the worker a greater share of the products of his labor. Laws were passed requiring that women workers should be paid a wage sufficient at least to sustain them in health and morals. Again the majority of the court asserted that such an attempt was beyond the power of government.57 This law, it was said, "forbids two parties having lawful capacity . . . to freely contract with one another in respect of the price for which one shall render service to the other in a purely private employment. ... . The law takes account of the necessities of only one party to the contract. It ignores the necessities of the employer by compelling him to pay not less than a certain sum, not only whether the employee is capable of earning it, but irrespective of the ability of his business to sustain the burden. . . . . It compels him to pay at least the sum fixed in any event, because the employee needs it, but requires no service of equivalent value from the employee. ....

"To the extent that the sum fixed exceeds the fair value of the services rendered, it amounts to a compulsory exaction from the employer for the support of a partially indigent person, for whose condition there rests upon him no peculiar responsibility, and therefore in effect, arbitrarily shifts to his shoulders a burden, which, if it belongs to anybody, belongs to society as a whole. . . . . Certainly the employer, by paying a fair equivalent for the service rendered, though not sufficient to support the employee, has neither caused nor contributed to her poverty. On the contrary to the extent of what he pays he has relieved it. . . . It has been said that the legislation now under review is required in the interest of social justice, for

\footnotetext{
${ }^{56}$ Supra, note 54, 17 . There were strong dissenting opinions in both the Adair and Coppage cases. Truax v. Corrigan, 257 U.S. 3 I2, 42 Sup. Ct. 124, 66 L.Ed. 254 (I92I), holding that the equal protection of the law clause of the Fourteenth Amendment is violated by a state statute which deprives the employer of the remedy of injunction for certain injuries to his business by striking employees, also indicates the unfriendliness of the majority of the Court to legislation favoring labor in its struggle with capital. The effect of Texas \& N. O. R. Co. v. The Brotherhood, $28 \mathrm{r}$ U.S. 548,50 Sup. Ct. 427, 74 L.Ed. I034 (r930), sustaining an act of Congress prohibiting a railroad from interfering with the employee's choice of representatives under the Railway Labor Act of 1926 , is still uncertain. See Sharp, Movement in Supreme Court Adjudication, 46 Harv. L. Rev. 36r, 388 (I933):
}

57 Adkins v. Children's Hospital, $26 x$ U.S. 525, 43 Sup. Ct. 394, 67 L.Ed. 785 (x923). 
whose ends freedom of contract may lawfully be subjected to restraint. The liberty of the individual to do as he pleases is not absolute. It must frequently yield to the common good. . . . . But nevertheless there are limits to the power, and when these have been passed it becomes the plain duty of the courts in the proper exercise of their authority to so declare. To sustain the individual freedom of action contemplated by the Constitution is not to strike down the common good but to exalt it; for surely the good of society as a whole cannot be better served than by the preservation against arbitrary restraint of the liberties of its constituent members." 58 Apparently the dictate of the German, Stammler, that "every power of control conferred by law can be justified only in the sense that the individual subject thereto can yet exist as a fellow creature," has no place in American constitutional law. ${ }^{59}$

Governmental limitation upon the prices charged by vendors of goods and services has leaned for support on the concept of a business affected with a public interest. ${ }^{60}$ For nearly half a century it appeared that here was a principle which would enable the state to check in behalf of the consumer, as the shifting conditions of business might require, the charges of the producer. In the pioneer case of Munn v. Illinois ${ }^{6 \mathrm{x}}$ the court sustained the fixing of storage charges for grain elevators in the City of Chicago. "When private property is 'affected with a public interest it ceases to be a jus privati only'. . . . Property does become clothed with a public interest when used in a manner to make it of public consequence, and affect the community at large. When, therefore, one devotes his property to a use in which the public has an interest, he in effect grants to the public an interest in that use, and must submit to be controlled by the public for the common good. ...." Because of the important part played by the Chicago elevators in the commerce of the nation, it was held that the business came within the declared rule, and the fact that there was no precise precedent for the regulation was immaterial. The case was one "for the application of a long-known and well-established principle in social

$5^{8}$ Ibid., 554-56r.

s9 Rudolph Stammler, Lehre von dem richtigen Recht, 208-21I, quoted in Pound, Outlines of Lectures on Jurisprudence (1920), 55 .

$\omega$ "It must be conceded that all businesses are subject to some measure of public regulation," from the opinion of Mr. Justice Sutherland in New State Ice Co. v. Liebmann, 285 U.S. 262, 273, 52 Sup. Ct. 37r, 372 (r932). Senator Wagner of New York, speaking on behalf of the National Industrial Recovery Act before the House Committee on Ways and Means, stated, "This bill makes explicit the principle that all business is affected with the public interest." Quoted in 40 American Federationist (July I933), 689.

${ }^{6} 94$ U.S. $x x_{3}(1877)$. 
science, and this statute simply extends the law so as to meet this new development of commercial progress." ${ }^{2}$ At the same term of court statutes fixing railroad rates were also sustained. ${ }^{63}$ In strong and vigorous opinions the court later reaffirmed the principles of Munn v. Mllinois and sustained the regulation of prices not only for grain elevators, ${ }^{64}$ but also for fire insurance companies ${ }^{65}$ and for carriers of oil by means of pipe lines. ${ }^{66}$ The Court, however, later receded from this advanced position. In Chas. Wolff Packing Co. v. Court of Industrial Relations, ${ }^{67}$ the state of Kansas, in an endeavor to deal with industrial strikes, declared that the manufacture and transportation of food, clothing, and fuel were businesses affected with a public interest and subject to public control for the purpose of assuring a continuous supply of these necessities. A unanimous court frowned upon the idea. Businesses affected with a public interest were limited to three categories: (I) those where some special privilege granted by the state was enjoyed; (2) certain occupations regarded for historical reasons as exceptional, e.g., inns and gristmills; (3) those in which the public has a particular claim under the principle of Munn v. Illinois. The court speaking through Mr. Chief Justice Taft, showed a reluctance to extend the third category. "In a sense the public is concerned about all lawful business because it contributes to the prosperity and well being of the people. The public may suffer from high prices or strikes in many trades, but the expression 'clothed with a public interest' as applied to business, means more than that the public welfare is affected by continuity or by the price at which a commodity is sold or a service rendered. ... . It has never been supposed, since the adoption of the Constitution, that the business of the butcher, or the baker, the tailor, the wood chopper, the mining operator, or the miner was clothed with such a public interest that the price of his product or his wages could be fixed by state regulation. .... Nowadays one does not devote one's property or business to the public use or clothe it with a public interest merely because one makes commodities for, and sells to, the public in the common callings of which those above mentioned are instances." 68

${ }^{62}$ Ibid., 126 and $\mathrm{r} 33$.

${ }_{63}$ Chicago, Burlington, and Quincy R.R. v. Iowa, 94 U.S. 155 , 24 L.Ed. 94 (1877), and other cases.

64 Budd v. New York, I43 U.S. 517, I2 Sup. Ct. 468, 36 L.Ed. 247 (1892); Brass v. North Dakota, I 53 U.S. 39I, I4 Sup. Ct. 857, 38 L.Ed. 757 (1894).

${ }_{65}$ German Alliance Insurance Co. v. Lewis, 233 U.S. 389,34 Sup. Ct. 612,58 L.Ed. Ior I (IgI4).

${ }^{66}$ United States v. Ohio Oil Co., 234 U.S. 548, 34 Sup. Ct. 956, $5^{8}$ L. Ed. 1459 (I9I4).

${ }_{67}^{6} 6_{2}$ U.S. $5^{22}, 43$ Sup. Ct. 630, 67 L.Ed. $\operatorname{Iro}_{3}$ (I923).

${ }^{68}$ Ibid., 535-537. 
In the three cases of Tyson v. Banton, ${ }^{69}$ Ribnick v. McBride, ${ }^{70}$ and Williams v. Standard OiJ Co. ${ }^{7 x}$ involving the fixing of prices for resold theater tickets, employment agencies, and gasoline, the retreat from Munn v. Illinois became almost a rout. The principle that property "becomes clothed with a public interest when used in a manner to make it of public consequence and affect the community at large" could not, said Mr. Justice Sutherland, who wrote the majority opinion in all three cases, be generally applied, but must be confined to the specific facts of the Munn case. Stated affirmatively, "a business in order to be affected with a public interest must be such or be so employed as to justify the conclusion that it has been devoted to a public use and its use thereby in effect granted to the public." "72 The italics are Mr. Justice Sutherland's and his meaning is made clearer by the example he uses of a public street opened upon private land, and by the contrast between his statement of the principle with that of Mr. Justice Stone, ${ }^{73}$ dissenting, "Price regulation . . . . is within a state's power whenever any combination of circumstances seriously curtails the regulative force of competition so that buyers or sellers are placed at such a disadvantage in the bargaining struggle that a legislature might reasonably anticipate serious consequences to the community as a whole." 74

The statutes regulating the labor contract, and fixing prices of commodities and services were designed for the immediate benefit of the worker and the consumer. The National Industrial Recovery Act, and much of the new state legislation rests, however, on the broader base of a general public interest, and on a conviction that the national welfare, if not the very safety of the country, requires a governmental control over previous private interests. Unfortunately, however, when direct group

${ }_{9}{ }_{273}$ U.S. 4 I8, 47 Sup. Ct. 426 , 7 I L.Ed. 7 I8 (1927).

${ }^{70} 277$ U.S. 350,48 Sup. Ct. 545,72 L.Ed. 913 (1928).

${ }_{72} 278$ U.S. 235,49 Sup. Ct. Ir5 (I929).

72 Tyson v. Banton, supra, note 69,434 . This statement was repeated in the two subsequent cases.

${ }^{23}$ Ribnick v. McBride, supra, note 70,359 . The position of the majority in these three cases is substantially that of Justices Field and Brewer dissenting in Munn v. Illinois and Budd v. New York, supra, notes $6 \mathrm{r}$ and 64 .

74 The two later cases of Tagg Bros. v. United States, 280 U.S. 420, 50 Sup. Ct. 220, 74 L.Ed. $5^{24}$ (I930), and O'Gorman \& Young v. Hartford Fire Ins. Co., 282 U.S. 251 , 5 I Sup. Ct. 130,75 L.Ed. 324 (193r) sustaining respectively the regulation of the charges of commission men in live stock yards, and of insurance agents' commissions for writing fire insurance do not overrule the cases just discussed. The power to regulate in these last two cases was based on the fact that the subject matter directly affected was an integral part of a larger business, over which the state's control had already been established. 
interest has been lacking.and a statute proposes to regulate so-called private business for the welfare of that omnipresent, but not usually vocal third party, the general public, it has found even less sympathy from our Supreme Court. In Chas. Wolff Packing Company v. Court of Industrial Relations, ${ }^{75}$ the state of Kansas endeavored to grapple with the problem of the strike in industry with its attendant public injury by granting to the state the power to settle the differences between employer and employees to the end that the public might not be damaged through cessation in the supply of food, fuel, or other necessities of life. In the words of Mr. Chief Justice Taft, "The necessary postulate of the Industrial Court Act is that the state, representing the people, is so much interested in their peace, health, and comfort that it may compel those engaged in the manufacture of food and clothing, and the production of fuel, whether owners or workers, to continue in their business and employment on terms fixed by an agency of the state, if they cannot agree." "76 Compared with recent proposals for state control over industry the Kansas experiment seems a mild one, and yet the Court by a unanimous opinion, held it unconstitutional. Such recognized liberal thinkers as Mr. Justice Holmes and Mr. Justice Brandeis did not even give it the comfort of noting a dissent. ${ }^{77}$ Even assuming that the production of the necessities of life might come within the category of "businesses affected with a public interest" the court denied that the state might, against the owner's desires, compel him to operate his establishment for the benefit of the public, and if that were true as to the owner, then a fortiori, much more would it be true as to the employee. This obligation to render a continuing service to the public "can only arise when investment by the owner and entering the employment by the worker create a conventional relation to the public somewhat equivalent to the appointment of officers and the enlistment of soldiers in military service." $7^{8}$ On the first appearance of the case before the Supreme Court the order of the Court of Industrial Relations fixing wages was held constitutionally ultra vires. On the second appearance a like order fixing hours of labor was also condemned. ${ }^{79}$ It was not the wage-fixing feature of the first order that invalidated it, but the claim of general power to regulate between employer and employee the terms of their contract, in order

${ }_{75} 262$ U.S. 522, 43 Sup. Ct. 630, 67 L.Ed. II03 (I923).

${ }^{7} \mathrm{Ibid}$., 533 .

nThis may be explained on the ground that neither the employing nor the employed classes, those most directly concerned in the legislation at hand, favored its enactment.

${ }^{78}$ Supra, note $75,54 \mathrm{I}$.

${ }_{79}$ Chas. Wolff Packing Co. v. Court of Industrial Relations, 267 U.S. 552, 45 Sup. Ct. 44I, 69 L.Ed. 785 (I925). 
to protect the public interest by preventing a paralysis of essential industries. If this be true, is it within the power of the state to compel employers and employees to shorten the working day, probably against their own personal interests, in order that those otherwise unemployed may be given a portion of the work performed by those already employed?

New State Ice Company v. Liebmann ${ }^{80}$ arose nearly ten years after the Kansas Industrial Court cases and was decided in the midst of the present economic depression. A statute of Oklahoma gave to the State Corporation Commission power to deny to any person the right to enter into the business of manufacturing ice, if in the opinion of the Commission there were already sufficient facilities to meet the public demands in that respect. The majority of the Court denied that the manufacture of ice could be considered a public calling, and held that any "regulation which has the effect of denying or unreasonably curtailing the common right to engage in a lawful private business . . . . cannot be upheld consistent with the Fourteenth Amendment." 8 I Experimentation by the state of Oklahoma in this direction was therefore forbidden. This time, however, Mr. Justice Brandeis and Mr. Justice Stone protested against the decision of their fellow justices. ${ }^{82}$ This was partly on the ground that under peculiar local conditions the manufacture of ice in Oklahoma might well be considered a public utility. But Mr. Justice Brandeis went further. By the time his opinion was written the economists and publicists of the nation were mobilizing their plans to deal with our financial and business crisis. To their proposals the dissenting judges were at least tolerant. "The people of the United States are now confronted with an emergency more serious than war. Misery is widespread in a time, not of scarcity, but of over-abundance. . . . . Rightly or wrongly, many persons think that one of the major contributing causes has been unbridled competition. Increasingly, doubt is expressed whether it is economically wise, or morally right, that men should be permitted to add to the producing facilities of an industry, which is already suffering from over-capacity. . . . . They assert that through improved methods of manufacture made possible by advances in science and invention and vast accumulations of capital, our industries had become capable of producing from 30 to too per cent more than was consumed even in the days of vaunted prosperity; and that the present capacity will, for a long time, exceed the needs of business. All

${ }_{80} 285$ U.S. 262,52 Sup. Ct. 37 I, 76 L.Ed. 747 (I932). 8I Ibid., 278.

82 Mr. Justice Cardozo did not partake in the consideration or decision of the case. It may confidently be assumed that had he done so his attitude would have been the same as that of Justices Brandeis and Stone. 
agree that irregularity in employment-the greatest of our evils-cannot be overcome unless production and consumption are more evenly balanced. Many insist that there must be some form of economic control. There are plans for proration. There are many proposals for stabilization. And some thoughtful men of wide business experience insist that all projects for stabilization and proration must prove futile unless, in some way, the equivalent of the certificate of public convenience and necessity is made a prerequisite to embarking new capital in an industry in which the capacity already exceeds the production schedules." ${ }_{3}$ The learned Justice recognized that the proposal was fraught with difficulties, but thought nevertheless that the Court should not oppose its will if "a single courageous state" chose to "serve as a laboratory" for trying "novel social and economic experiments." ${ }_{4}$ Apparently the "New Deal" has obtained sympathetic consideration from at least a minority of the members of the Supreme Court.

\section{IV}

Much of this new legislation is indeed of a frankly temporary and emergency character. The National Industrial Recovery Act rests on the declaration of a national emergency and is limited to a space of two years after its enactment, unless the President shall sooner declare the emergency ended. As such there is good ground to believe that it may be sustained. In Wilson v. New, ${ }^{85}$ at the time of a threatened nation-wide railroad strike, a five to four majority of the United States Supreme Court sustained the fixation of wages and hours of railroad employees. While "an emergency may not call into life a power which has never lived, nevertheless emergency may afford a reason for the exertion of a living power already enjoyed." 86 In the time of acute housing shortage and high rents after the World War the same five to four majority in the Court sustained the regulation of rents by a governmental commission. ${ }^{87}$ The first of these decisions rested its approval of the legislation on the ground that the

${ }^{83}$ Supra, note 80, 306 -309. The dissent is heavily annotated with references to scientific and popular articles on economic planning.

${ }^{84}$ See statement of the Honorable Alfred E. Smith, infra, note Iro.

85243 U.S. 332,37 Sup. Ct. 298, 6I L.Ed. 755 (I9I7).

${ }^{86}$ Ibid., 348.

${ }^{87}$ Block v. Hirsh, 256 U.S. I35, 4I Sup. Ct. 458, 65 L.Ed. 865 (I92I); Marcus Brown Holding Co. v. Feldman, 256 U.S. I70, 4 r Sup. Ct. 465,65 L.Ed. 877 (I921); Levy Leasing Co. v. Siegel, $25^{8}$ U.S. 242, 42 Sup. Ct. 289, 66 L.Ed. 595 (I922). In Chastleton Corporation v. Sinclair, 264 U.S. 543, 44 Sup. Ct. 405, 68 L.Ed. 84 I (r924) it was held that when the emergency was over, such acts ceased to be valid. 
emergency had so changed circumstances as to clothe with a public interest "what at other times or in other places would be a matter of purely private concern." A later decision reaffirming this position relied, moreover, on a more general exposition of the police power. "The warrant for this legislative resort to the police power was a conviction on the part of the state legislators [i.e., of New York] that there existed in the larger cities of the state a social emergency caused by an insufficient supply of dwelling houses and apartments so grave that it constituted a serious menace to the health, morality, comfort, and even to the peace of a large part of the people of the state. That such an emergency if it really existed would sustain a resort, otherwise valid, to the police power for the purpose of dealing with it cannot be doubted, for unless relieved, the public welfare would suffer in respects which constitute the primary and undisputed, as well as the most usual, basis and justification for exercise of that power." 88 That the present economic depression presents an almost unparalleled emergency, periling the morals, health, and lives of the people, and even the existence of the state itself, few can deny, and it is hardly to be expected that the Supreme Court will do so. We have no data for determining in such crises what measures of relief are permissible. In the terrific trial of the Civil War the safety of the state constituted sufficient warrant for the issuance by the federal government of fiat money as a means for preserving the government in its struggle for existence. ${ }^{89}$ The present machinery for industrial recovery is certainly no more than is necessary to restore prosperity to the land, and even that may fail. It is useless casuistry to ask whether in times of emergency the constitution may be deemed suspended, or whether its provisions are broad and flexible enough to permit the exercise of powers not ordinarily usable: In any event, there is ample authority for the proposition that in such times as

${ }^{88}$ Levy Leasing Co. v. Siegel, supra, note 87,245 . In Block v. Hirsh, supra, note $87, \mathrm{Mr}$. Justice McKenna, dissenting, feared the possible extension of the doctrines of the case. "If such an exercise of government be legal, what exercise of government is illegal? Houses are a necessary of life, but other things are as necessary. May they, too, be taken from the direction of their owners and disposed of by the government? .... It is to be remembered that the legality of power must be estimated, not by what it will do, but by what it can do. . . . . The facts are significant and suggest the inquiry, have conditions come not only to the District of Columbia, embarrassing the Federal Government, but to the world as well, that are not amenable to passing palliatives, and that Socialism, or some form of Socialism, is the only permanent corrective or accommodation? It is indeed strange that this court, in effect, is called upon to make way for it and through the instrument of a Constitution based on personal rights and the purposeful encouragement of individual incentive and energy, to declare legal a power exerted for their destruction."

${ }^{89}$ Legal Tender Cases, I2 Wall. 457 (I87 I). 
these customary private interests must be subordinated to what is deemed the needs of the public welfare and safety. ${ }^{90}$

A disposition of the problem purely as an emergency measure can, however, hardly be permanently satisfactory. While some of the advocates of the new departure of government into fields of economic control stress its temporary and emergency character, others view it as of a much broader and more enduring nature. To the chief executive of the nation, the National Industrial Recovery Act "represents a supreme effort to stabilize for all time the many factors which make for the prosperity of the nation." An emergency measure to expire within two years, or until the end of the present economic crisis, hardly justifies the appellation of a "revolution" given to it by Mr. Donald Richberg. ${ }^{92}$ The prophets of the new order are proposing not temporary measures to be applied only while disaster is imminent, but fundamental and enduring planning during times of normal prosperity in order that subsequent catastrophe may be averted. ${ }^{93}$ The acute suffering we are now experiencing is recognized to have had its origin in the over-production of the years of prosperity and the lack of a purchasing power in the great mass of society to consume the output of our great national industrial and agricultural machine. It is a condition likely again to occur in an unregulated economic state if and when prosperity is restored. Many of the measures proposed can indeed operate satisfactorily only when the country is on an even economic keel. The great experiment is right now facing possible disaster by an artificial increase in prices, when delayed prosperity still leaves millions unemployed and millions of others with purchasing power greatly reduced by assets frozen in closed banks, and the return from investments in stocks and mortgages completely vanished. There is now little need to restrict new additions to our capital structure. Unemployment reserves are hard to establish and are apt to be ineffective when thousands of businesses are

${ }_{90}$ People v. Nebbia, I86 N.E. 694, decided July Ir, I933, by the New York Court of Appeals, held constitutional an act regulating the milk business and authorizing the milk control board to fix minimum wholesale and retail prices. (See note 33, supra.) Southport Petroleum Co. v. Ickes (see C.C.H. Fed. Trade Regl. Service, 7th ed., 5203) decided Aug. I5, I933, by the Supreme Court of the Dist. of Columbia, held constitutional section $q$ (c) of the N.I.R.A. Economy Dairy Co. v. Wallace (C.C.H. Fed. Trade Regl. Service, 7 th ed., 520r) decided Aug. 29, 1933, by the same court, held constitutional the Agricultural Adjustment Act. Blaisdell v. Home Bldg. and Loan Assn., 249 N.W. 334 (Minn., July 7, x933) held constitutional as an emergency measure, in spite of the contract clause of the federal constitution, a legislative extension of the period of redemption from mortgage foreclosures. See contra, State ex. rel. Cleveringa v. Klein, 249 N.W. rx8 (N.D., June 12, 1933).

9r See note 39, sicpra.

${ }_{92}$ See note 44 , supra.

93 See notes $27,28,29$, supra. 
on the verge of bankruptcy and millions of workers are out of employment." The "New Deal" means not only extraordinary emergency legislation but the dawn of a new political and economic era.

\section{$\mathrm{V}$}

If the Supreme Court is to sustain redistribution of purchasing power and economic planning through direct regulation, it is apparent that the attitudes displayed and the principles enunciated in Coppage v. Kansas, ${ }^{95}$ Chas. Wolff Packing Co. v. Court of Industrial Relations ${ }^{96}$ and Adkins v. Children's Hospital ${ }^{97}$ must be renounced. The individualistic thought and action displayed in those and kindred cases must be reversed by a change in philosophic attitude, and a development of a tradition of the social responsibility of the individual..$^{88}$ If this cannot be done, speculation is rife as to the possibility of creating a new philosophy by various methods of packing the Court. ${ }^{99}$

For the court to renounce, repudiate, or ignore the more extreme of its individualistic pronouncements would not, however, be an entirely novel phenomenon. "It is a peculiar virtue of our system of law that the process of inclusion and exclusion so often employed in developing a rule, is not allowed to end with its enunciation, and that an expression in an opinion yields later to the impact of facts unforeseen." empirical and pragmatic. It grows largely from case to case, and not by logical deductions from declared general premises. The belief of Marshall in McCulloch v. Maryland, ${ }^{\text {ror }}$ that, for the purpose of determining the

94 In Chap. I86, Laws of Wisconsin 1933, the compulsory operation of the Wisconsin Unemployment Reserves Act was extended "until business recovery is well under way in Wisconsin."

${ }_{95}$ See note 54, supra.

${ }^{96}$ See note 67 , supra.

${ }_{97}$ See note 57 , supra.

${ }^{83}$ See A. A. Berle, Jr., A High Road For Business, in Scribner's Magazine, June 1933, 325; Tugwell; op. cit., supra, note $27,3-7$; Alfred E. Smith, note I 1o, infra. Compare the following paragraph from Sharp, supra, note 56, 809: "Individualistic habits will probably not soon disappear. Mental and civic individualism may in fact be more than ever essential if other depressions in time produce what some expect, a relatively co-operative industrial system. If technical and administrative developments do indeed require the creation of new types of cooperative social and industrial organizations, and the extension of social control, it is possible to expect that such developments will not meet a permanent obstacle in the decisions of the Supreme Court. The wisdom of the Court has led it throughout its history to recognize the necessity for practical adjustments in its administration of justice."

99 Paul Y. Anderson, If the Supreme Court Objects, The Nation, July 19, I933, 64.

${ }^{100} \mathrm{Mr}$. Justice Brandeis, dissenting, in Jaybird Mining Co. v. Weir, 27I U.S. 609, 6I9, 46 Sup. Ct. 592, 595 (1926).

${ }^{\text {sor }} 4$ Wheat. 316 (I8I9). 
boundary between immunity of federal instrumentalities and the power of the states, he had discovered in the principle of sovereignty "an intelligible standard, applicable to every case to which the power may be applied" was certainly not realized in the following years. The original dogma that a corporation is a creature of the law, having no existence beyond the borders of the state that created it, had to yield to the practical exigencies of commerce. ${ }^{122}$ The litigation over the commerce clause is strewn with the broken fragments of attempts at definition and generalization, and the court at times has openly confessed that its decisions have been dictated more by considerations of practical expediency than by the logical application of declared legal principles. ${ }^{\text {I03 }}$ Moreover, pure individualism has never been maintained in our law. The hirer of labor may be prohibited from offering as the price of wages hours of work detrimental to the health of his employees. ${ }^{\text {x }} 4 \mathrm{~A}$ business may be prohibited not because it, in itself, is a menace to the public good, but because it is one of a class in which that menace does exist and for administrative purposes it is impractical for the law to do other than generalize. ${ }^{\text {xos }}$ Taxation has often been used as a means of directing economic life along certain channels, ${ }^{\text {ro6 }}$ and regulatory statutes have been sustained which except from their operation certain groups and classes believed to be in need of economic aid rather than of restriction. ${ }^{\text {.07 }}$

That drastic governmental control over industry teems with perils must be admitted. In his dissent in New State Ice Co. v. Leibmann, ${ }^{\text {,08 }} \mathrm{Mr}$. Justice Brandeis observed, "The objections to the proposal are obvious and grave. The remedy might bring evils worse than the present disease. The obstacles to success seem insuperable. The economic and social sciences are largely unchartered seas. We have been none too successful in the modest essays in economic control already entered upon. The new pro-

${ }^{102}$ Henderson, The Position of the Foreign Corporation in American Constitutional Law (I918); Note, 3 Wis. L. Rev. roo (I925).

${ }^{103}$ Galveston, etc. Ry. v: Texas, 210 U.S. 217,28 Sup. Ct. 638 (I908).

${ }_{104}$ Bunting v. Oregon, 243 U.S. 426, 37 Sup. Ct. 435, 6r L.Ed. 830 (I9I7).

${ }_{105}$ Powell v. Pennsylvania, I27 U.S. 678, 8 Sup. Ct. 992, 32 L.Ed. 253 (I887).

${ }^{106}$ American Sugar Refining Co. v. Louisiana, I79 U.S. 89, 2x Sup. Ct. 43, 45 L.Ed. ro2 (I900); Quong Wing v. Kirkendall, 223 U.S. 59, 32 Sup. Ct. I92, 56 L.Ed. $35^{\circ}$ (I9I2).

${ }^{10} 7$ In this respect the law appears to have progressed to the position stated in the text. Cf. Connolly v. Union Sewer Pipe Co., I84 U.S. 540, 22 Sup. Ct. 43r, 46 L.Ed. 679 (I902) with International Harvester Co. v. Missouri, 234 U.S. r9g, 34 Sup. Ct. 859, 58 L.Ed. 1276 (I9I4) and Liberty Warehouse Co. v. Burley Tobacco Growers Ass'n., 276 U.S. 7I, 48 Sup. Ct. 29 I (1928). In the last case the aid given to agricultural co-operatives was of a positive and not merely negative character.

${ }^{308}$ Suspra, note 8o. 
posal involves a vast extension of the area of control. Merely to acquire the knowledge essential as a basis for the exercise of this multitude of judgments would be a formidable task; and each of the thousands of these judgments would call for some measure of prophecy. Even more serious are the obstacles to success inherent in the demands which exécution of the project would make upon human intelligence and upon the character of men. Man is weak and his judgment is at best fallible."'rog The Hon. Alfred E. Smith has recently expressed similar doubts as to the wisdom of the N.I.R.A." "I have never hesitated to recommend the extension of government activities to meet the needs of a growing population in an age of industrial invention, but this plan goes beyond anything my imagination can follow. I may be old-fashioned, but I can't understand how it can possibly work. . . . . If we could give the planners a corner of Alaska, or a chunk of the Bad Lands, for their experiment, it would not be so serious. Then if the laboratory blew up, the whole nation would not suffer." ${ }^{\prime I I}$ A little farther on Mr. Smith states, "In such a triumph of bureaucracy, the little man would be lost in the shuffle." It is interesting to compare this last with President Roosevelt's emphasis upon, and plea to, the little man to co-operate, in his radio address of July 24 , I933. . $^{\text {x2 }}$

It is entirely possible, of course, that some governmental acts under a scheme of social planning will be directed not to the welfare of society as a whole, but to ignoble ends of partisanship and class favoritism. The Fourteenth Amendment, unless it is to be totally repudiated, should, it is clear, be applied to annul arbitrary acts of spoliation and discrimination. And yet it is extremely difficult to draw the line between the good and the evil law. Is the current agitation against the chain store designed to foster the common weal, or is it merely to protect the independent merchant? Suppose new labor-saving devices are discovered reducing drastically the cost of the product to the consumer, but throwing thousands of workers out of employment. Would suppression or restriction of the new invention be in the interests of society, or an act of favoritism to the vested interests of capital and labor in the old industry? It is apparent that such questions

soo Supra, note 8o, 309 .

${ }^{210}$ Alfred E. Smith, Business Control, in the New Outlook, July, 1933, 9-10.

ur Compare the language of $\mathrm{Mr}$. Justice Brandeis on the locale of experimentation, in his dissenting opinion in New State Ice Co. v. Liebmann, supra, note 80, especially at 31 I, “It is one of the happy incidents of the federal system that a single courageous State may, if its citizens choose, serve as a laboratory; and try novel social and economic experiments without risk to the rest of the country."

$\mathrm{In}$ "But, important as is the heartening demonstration, the richest field for results is among the small employers, those whose contribution will give new work for from one to ten people." 
as these cannot be answered by use of the customary dogmas of our legal system. If large scale economic planning is to be attempted, it seems clear that a new hierarchy of governmental agencies must be established to administer the difficult technological, financial, and human problems that the proposal entails. Judicial control can be only remote and supervisory, as is now the situation in relation to most administrative bureaus.

The importance of the judgments the Supreme Court must make when the program for the "New Deal" is presented to it cannot be minimized. The American principle of judicial review declared in Marbury v. Madison, ${ }^{\mathrm{Ix} 3}$ and the due process clause of the Fourteenth Amendment have made the Court the battlefield on which competing political, social and economic theories wage their Armageddons. Thus the Court will be called upon to decide whether, under our Constitution, the nation must in matters economic be ruled largely by a spirit of laissez faire, or whether the state may through the force of its members control the individual's rights of property and contract in the economic interest of the common society. Thrice in its long history the Supreme Court has wrestled with problems calling not so much for legal reason and acumen, as for the highest attributes of statesmanship. First, Marshall and his colleagues wrought from the vague generalities of the Constitution our federal system; then, in the era following the Civil War, the Court resisted the efforts of the radicals in Congress by drastic reconstruction to humble state power; and lastly, after the close of the Spanish-American War it was decided that no obstacle should be placed in the "path of empire" on which the nation had entered. It seems probable that the work on which the Court must shortly enter will, in its importance and effect on the nation's life, be fully comparable to the tasks already performed.

${ }^{r \times 3}$ I Cranch. 137 (I803). 